\title{
Enzymatic Degradation of Congo Red by Turnip (Brassica rapa) Peroxidase
}

\author{
Afaf Ahmedi ${ }^{\mathrm{a}}$, Mahmoud Abouseoud ${ }^{\mathrm{a}, \mathrm{b}, *}$, Annabelle Couvert ${ }^{\mathrm{c}}$, and \\ Abdeltif Amrane ${ }^{c}$ \\ a Laboratoire de Biomatériaux et Phénomènes de Transfert, Faculté des Sciences et de la \\ Technologie, Université Yahia Fares de Médéa, Pole Universitaire, RN1, Médéa, 26000, \\ Algeria. Fax: 0021325581253. E-mail: aseoud2002@yahoo.fr \\ b Laboratoire de Génie de la Réaction, Faculté de Génie Mécanique et Génie des \\ Procédés, Université Houari Boumediene, Bab Ezzouar, Alger, 16111, Algeria \\ c Ecole Nationale Supérieure de Chimie de Rennes, CNRS, UMR 6226, \\ Avenue du Général Leclerc, CS 50837, 35708 Rennes Cedex 7, France \\ * Author for correspondence and reprint requests \\ Z. Naturforsch. 67 c, 429-436 (2012); received August 2, 2011/June 28, 2012
}

The enzyme peroxidase is known for its capacity to remove phenolic compounds and aromatic amines from aqueous solutions and also to decolourize textile effluents. This study aims at evaluating the potential of a turnip (Brassica rapa) peroxidase (TP) preparation in the discolouration of textile azo dyes and effluents. An azo dye, Congo Red (CR), was used as a model pollutant for treatment by the enzyme. The effects of various operating conditions like $\mathrm{pH}$ value, temperature, initial dye and hydrogen peroxide concentrations, contact time, and enzyme concentration were evaluated. The optimal conditions for maximal colour removal were at $\mathrm{pH} 2.0,40{ }^{\circ} \mathrm{C}, 50 \mathrm{~mm}$ hydrogen peroxide, $50 \mathrm{mg} / \mathrm{l} \mathrm{CR}$ dye, and TP activity of $0.45 \mathrm{U} / \mathrm{ml}$ within $10 \mathrm{~min}$ of incubation time. Analysis of the by-products from the enzymatic treatment by UV-Vis and IR spectroscopy showed no residual compounds in the aqueous phase and a precipitate of polymeric nature.

Key words: Congo Red, Discolouration, Peroxidase

\section{Introduction}

Waste water effluents from various industries including dyeing, textile, dye manufacturing, leather, cosmetics, food processing, and paper are considered main sources of dye pollution (Bhatnagar and Jian, 2005). There are more than $10^{5}$ kinds of commercially available dyes with over $8 \cdot 10^{5}$ metric tons of dyestuff produced annually of which at least $10 \%$ are lost and released into industrial effluents (Palmieri et al., 2005). Nearly half of all known dyes are azo dyes which makes them the most abundant group of synthetic dyes (Selvam et al., 2003). These dyes are hardly degraded in the environment due to their resistance to oxidizing agents, light, and water (Meyer, 1981; O'Neill et al., 1999). Textile waste waters are characterized as having a strong colour, since some of the initial dye $(10-15 \%)$ is not fixed to the fiber during the dyeing process, thus being released into the effluents. When released into the environment without any treatment, they can cause serious contamination problems, de- creasing water transparency and, consequently, inhibiting the penetration of solar radiation and decreasing photosynthesis.

Treatment of dye-based effluents is considered a challenge to environmentalists. The main techniques described in the literature for the discolouration of wastewaters involve adsorption, precipitation, chemical degradation, electrochemical, photochemical, and biodegradation processes, among others (Guaratini and Zanoni, 2000). Microbial discolouration has been proposed as a cheaper and less environmentally aggressive alternative (Mohorcic et al., 2006). However, these procedures have not been widely used because of high cost, formation of hazardous by-products, and high energy requirement (Hai et al., 2007).

Recently, enzymatic approaches have attracted much interest in the removal of phenolic pollutants from aqueous solutions as a strategy alternative to the conventional chemical as well as microbial treatments that pose some serious limitations (Husain and Jan, 2000; Duran and 
Esposito, 2000; Yousefi and Kariminia, 2010). Oxidoreductive enzymes such as peroxidases and polyphenol oxidases participate in the degradation/removal of aromatic pollutants from various contaminated sites. These enzymes can act on a wide range of substrates and can also catalyze the degradation/removal of organic pollutants present at very low concentration at the contaminated site (Matto and Husain, 2009a). Considering the potential of these enzymes in treating phenolic compounds (QuintanillaGuerrero et al., 2008), several microbial and plant peroxidases and polyphenol oxidases have been considered for the treatment of dyes but none of them has been exploited on a large scale due to low enzymatic activity in biological materials and the high cost of purification (Bhunia et al., 2001; Shaffiqu et al., 2002). Enzymes can act on specific recalcitrant pollutants to be removed by precipitation or transformation into other innocuous products (Verma and Madamwar, 2002; Regalado et al., 2004).

In this study, a peroxidase preparation from turnip (Brassica rapa) (TP) was used in the transformation of Congo Red (CR) (Fig. 1) dye, which is commonly found in the contaminated aquifers of textile industries (Zhu et al., 2009; Chatterjee et al., 2007). This study documents TP- and $\mathrm{H}_{2} \mathrm{O}_{2}-$ mediated oxidation of $\mathrm{CR}$ dye and establishes some parameters of the reaction.

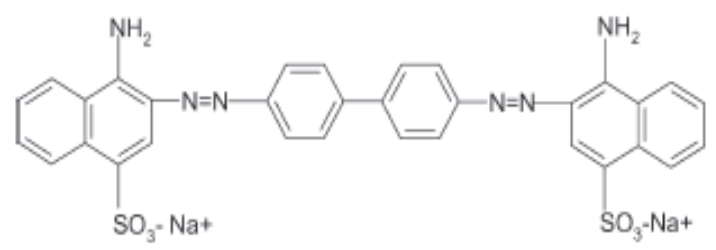

Fig. 1. Chemical structure of Congo Red.

\section{Material and Methods}

Dye

Congo Red dye (C.I., 22120; MW, 696.67 g/mol; $\lambda_{\max }, 499 \mathrm{~nm}$; dye content, $97 \%$ ) was supplied by Sigma-Aldrich (St. Louis, MO, USA). It belongs to the class of di-azo compounds, and its structure is shown in Fig. 1 (Purkait et al., 2007). The aqueous solution of the dye was prepared just prior to the experiments by dissolving the requisite amount of dye in distilled water.

\section{Extraction of $T P$}

Peroxidase was extracted from turnip (Brassica rapa L.) obtained locally (Matto and Husain, 2009b; Kulshrestha and Husain, 2007). Turnip (100 g) was cleaned and crushed in a wet grinder with the addition of $200 \mathrm{ml}$ distilled water. The homogenate was filtered through four layers of cheesecloth. The filtrate was subjected to fractionation by adding acetone. The mixture was stirred overnight at $4{ }^{\circ} \mathrm{C}$ to obtain maximum precipitation. The precipitate was collected by centrifugation at $4000 \times g$ in a Remi R-24 cooled centrifuge (Remi Laboratory Instruments, Mumbai, India). The resulting pellet was redissolved in $100 \mathrm{~mm}$ sodium phosphate buffer, $\mathrm{pH}$ 6.0.

\section{Enzyme assay}

TP activity was assessed by the 4-aminoantipyrene method using phenol and $\mathrm{H}_{2} \mathrm{O}_{2}$ as substrates and 4-aminoantipyrene as chromogen (Bhunia et al., 2001). The assay was performed at $25^{\circ} \mathrm{C}$ in phosphate buffer $(\mathrm{pH} 6.0)$ containing $2 \mathrm{~mm}$ phenol, $0.2 \mathrm{~mm}$ 4-aminoantipyrene and $2 \mathrm{mM} \mathrm{H}_{2} \mathrm{O}_{2}$ in a total volume of $5.2 \mathrm{ml}(1 \mathrm{ml}$ of dye $+1 \mathrm{ml}$ of $\mathrm{H}_{2} \mathrm{O}_{2}+3 \mathrm{ml}$ of buffer $+0.2 \mathrm{ml}$ of enzyme). The rate of $\mathrm{H}_{2} \mathrm{O}_{2}$ consumption in the assay was calculated from the rate of formation of the coloured product at $\lambda_{\max }=517 \mathrm{~nm}$ and a molar absorptivity of $5680 \mathrm{l} /(\mathrm{mol} \mathrm{cm})$.

One unit of activity (U) is defined as $\mu \mathrm{mol}$ $\mathrm{H}_{2} \mathrm{O}_{2}$ consumed per min.

Screening of peroxidase activity was similarly done on other plant sources (zucchini, cabbage, sweet potato, red radish, cauliflower, soybeans, and potato). Peroxidase was assayed in crude extracts in order to select the source giving the highest activity.

\section{Quantitative determination of dye concentration}

The dye concentration was determined spectrophotometrically at $\lambda_{\max }=500 \mathrm{~nm}$. After TP treatment, the sample was centrifuged and the residual dye concentration was determined in the supernatant (Kulshrestha and Husain, 2007).

\section{Enzymatic Congo Red degradation}

Initially, kinetics were determined in a series of vials containing $40 \mathrm{mg} / \mathrm{l}$ dye, $0.6 \mathrm{U} \mathrm{TP}$, and $20 \mathrm{~mm} \mathrm{H}_{2} \mathrm{O}_{2}$ and by varying the $\mathrm{pH}$ value of the aqueous phase of the reaction mixture between 
2 and 10. After incubation for $1 \mathrm{~h}$, followed by centrifugation at $4000 \times \mathrm{g}$ for $5 \mathrm{~min}$ at $24^{\circ} \mathrm{C}$, the residual dye concentration in the supernatant was determined. Subsequently, incubation time, dye concentration $(5-40 \mathrm{mg} / \mathrm{l}), \mathrm{H}_{2} \mathrm{O}_{2}$ concentration $(0.5-200 \mathrm{~mm})$, and TP concentration $(0.03-3 \mathrm{U} / \mathrm{ml})$ were varied to determine the optimal conditions for dye removal. All experiments were done in triplicate. Control (blank) experiments were performed without TP to assess abiotic degradation via photocatalytic or chemical processes.

\section{Calculation of the yield of discolouration}

The percentage of discolouration after enzymatic treatment was defined as:

dye removal $(R)=\frac{\left(A_{0}-A_{\mathrm{e}}\right)}{A_{0}} \cdot 100 \%$,

where $A_{0}$ and $A_{\mathrm{e}}$ are the absorbances before and after enzymatic treatment, respectively (Matto and Husain, 2009a, b).

\section{Analysis of degradation products}

After enzymatic CR discolouration, the reaction mixture was centrifuged, and the absorbance spectrum of the supernatant was determined in the UV-Vis region. The solid precipitate was vacuum-dried and analysed by infrared spectroscopy (FTIR) in the range of $4000-400 \mathrm{~cm}^{-1}$. The spectra were compared to those of CR.

\section{Results and Discussion}

\section{Extraction of peroxidase}

Extraction of peroxidase was performed on different plant sources, taking into account their

Table I. Peroxidase activity in different plant materials.

\begin{tabular}{lc}
\hline Peroxidase source & $\begin{array}{c}\text { Enzymatic } \\
\text { activity } \\
{[\mathrm{U} / \mathrm{ml}]}\end{array}$ \\
\hline White turnip (Brassica rapa) & 3.406 \\
Zucchini (Cucurbita pepo) & 2.189 \\
Cabbage (Brassica oleracea var. capitata) & 0.865 \\
Sweet potato (Ipomea batatas) & 0.481 \\
Red radish (Raphanus sativus) & 0.181 \\
Cauliflower (Brassica oleracea var. botrytis) & 0.074 \\
Potato (Solanum tuberosum) & 0.026 \\
\hline
\end{tabular}

availability and cost at local markets, to identify the source of the highest peroxidase activity. As seen in Table I, the highest peroxidase activity was found in Brassica rapa which was therefore chosen as the source of peroxidase for dye degradation.

\section{$p H$}

The dye was most effectively discoloured at $\mathrm{pH} 2.0$ (95\% during $1 \mathrm{~h})$, and there was a significant drop of activity above pH 5.0 (Fig. 2), similar to findings for horseradish peroxidase (Buhnia et al., 2001).

\section{Incubation time}

In mixtures containing $5 \mathrm{ml}$ of dye solution ( $40 \mathrm{mg} / \mathrm{l}), 0.6 \mathrm{U} / \mathrm{ml}$ of enzyme, $20 \mathrm{~mm}_{2} \mathrm{O}_{2}$ at $\mathrm{pH}$ 2.0 , and a temperature of $24{ }^{\circ} \mathrm{C}$, the reaction was rapid during the first $10 \mathrm{~min}$, and then leveled off, until there was no further reaction after about $1 \mathrm{~h}$ of incubation (Fig. 3).

\section{Temperature}

The reaction rate was little affected by temperatures between 20 and $40{ }^{\circ} \mathrm{C}$, but decreased sharply at higher temperatures (Fig. 4). A temperature of $25^{\circ} \mathrm{C}$ was therefore chosen.

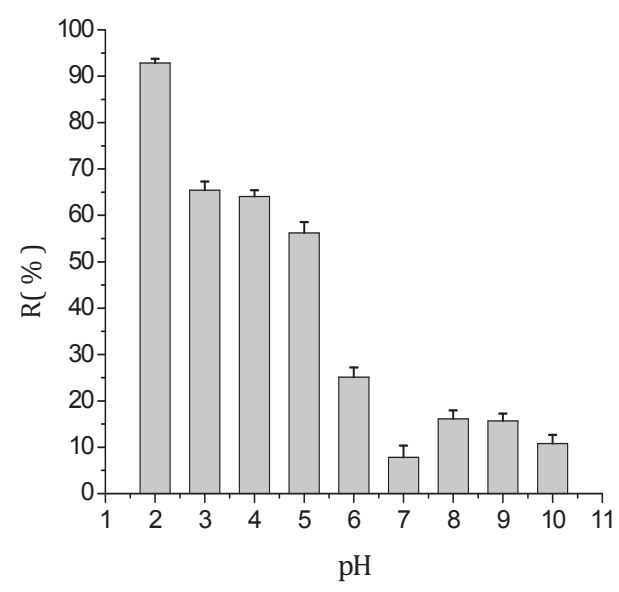

Fig. 2. Effect of $\mathrm{pH}$ value on the discolouration of Congo Red $(40 \mathrm{mg} / \mathrm{l})$ in the presence of $0.6 \mathrm{U} / \mathrm{ml}$ enzyme and $20 \mathrm{~mm} \mathrm{H}_{2} \mathrm{O}_{2}$, at $24{ }^{\circ} \mathrm{C}$ for 1 h. $R$, yield. 


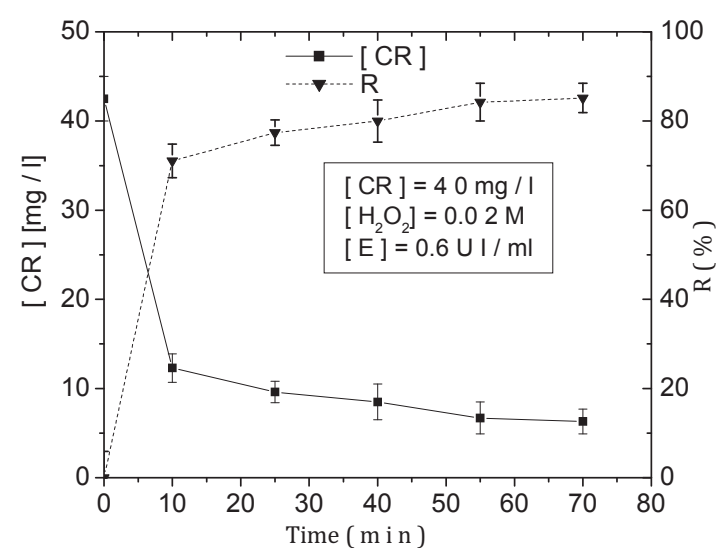

Fig. 3. Discolouration of Congo Red as a function of time. Other conditions as in Fig. 2.

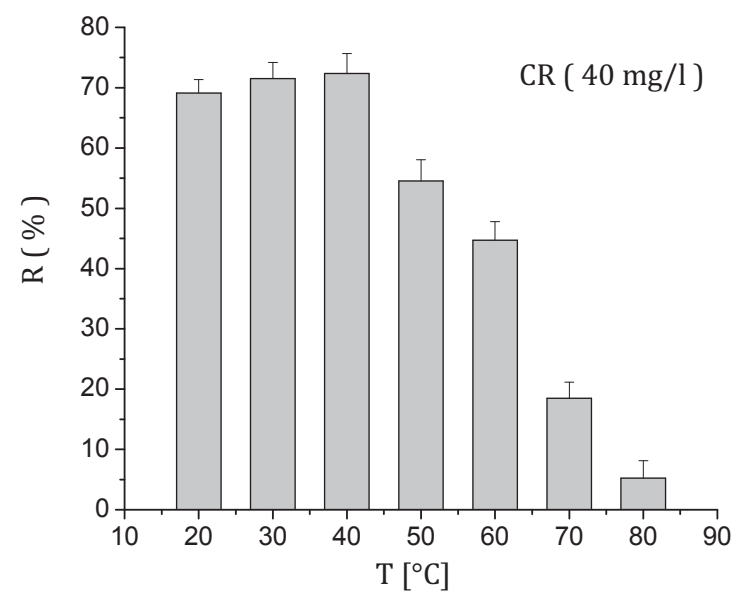

Fig. 4. Discolouration of Congo Red as a function of temperature. Other conditions as in Fig. 2.

\section{Dye concentration}

When dye concentrations were varied between 10 and $100 \mathrm{mg} / \mathrm{l}$, keeping the other parameters at constant values, the initial velocity $V_{0}$ was proportional to the concentration of the substrate until reaching a maximum at a dye concentration of $50 \mathrm{mg} / \mathrm{l}$ (Fig. 5). Further increase in dye concentration was accompanied by a decrease in the rate $V_{0}$, obviously due to substrate inhibition. On the other hand, the percent yield $R$ did not significantly change with increasing substrate concentration until $50 \mathrm{mg} / \mathrm{l}$ dye, with a rapid decrease at

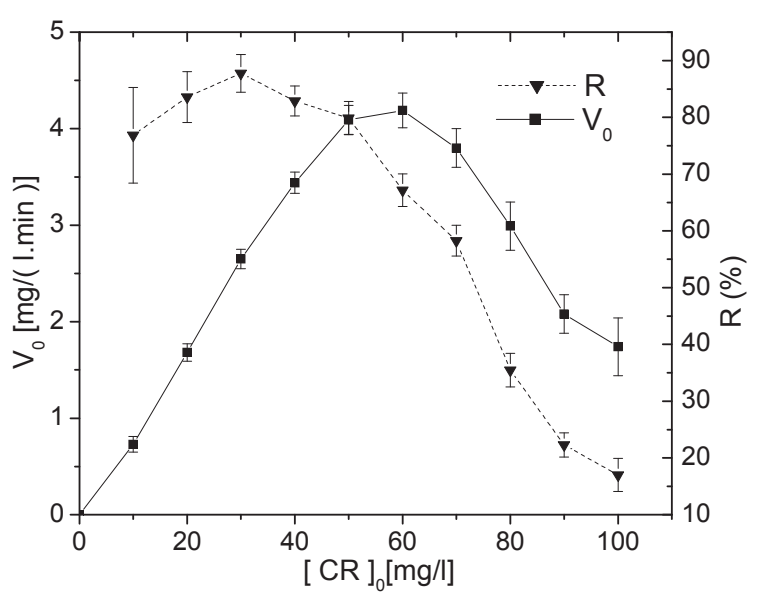

Fig. 5. Effect of substrate (Congo Red) concentration on the initial velocity $V_{0}$ and yield $R$ of Congo Red discolouration. Other conditions as in Fig. 2.

higher concentrations (Fig. 5). The optimal dye concentration was therefore $50 \mathrm{mg} / \mathrm{l}$, giving the highest yield at the highest initial rate.

\section{$\mathrm{H}_{2} \mathrm{O}_{2}$ concentration}

Varying the $\mathrm{H}_{2} \mathrm{O}_{2}$ concentration from 0.5 to $200 \mathrm{~mm}$ in the reaction mixture, keeping all other experimental conditions at their optimal values, gave the highest initial rate and yield at $50 \mathrm{~mm}$ $\mathrm{H}_{2} \mathrm{O}_{2}$ (Fig. 6), in agreement with the finding of other authors (Bhunia et al., 2001; Kulshrestha

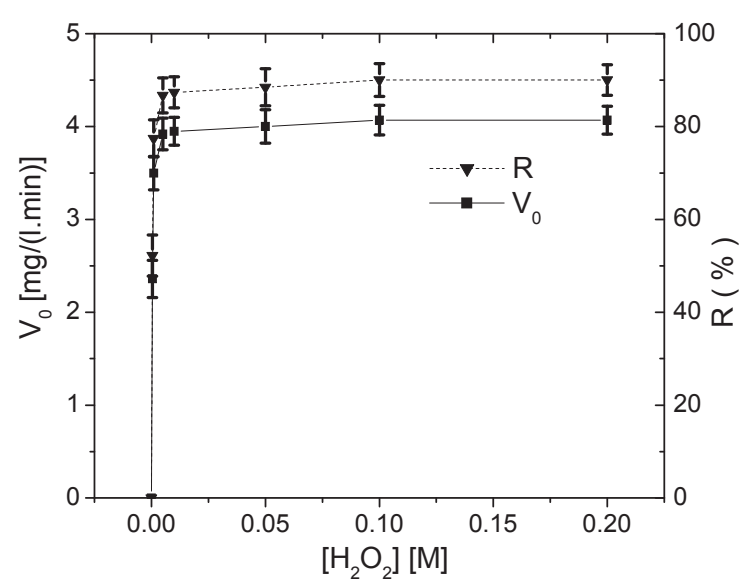

Fig. 6. Effect of substrate $\left(\mathrm{H}_{2} \mathrm{O}_{2}\right)$ concentration on Congo Red $(50 \mathrm{mg} / \mathrm{l})$ discolouration during a 10 -min incubation time. Other conditions as in Fig. 5. 


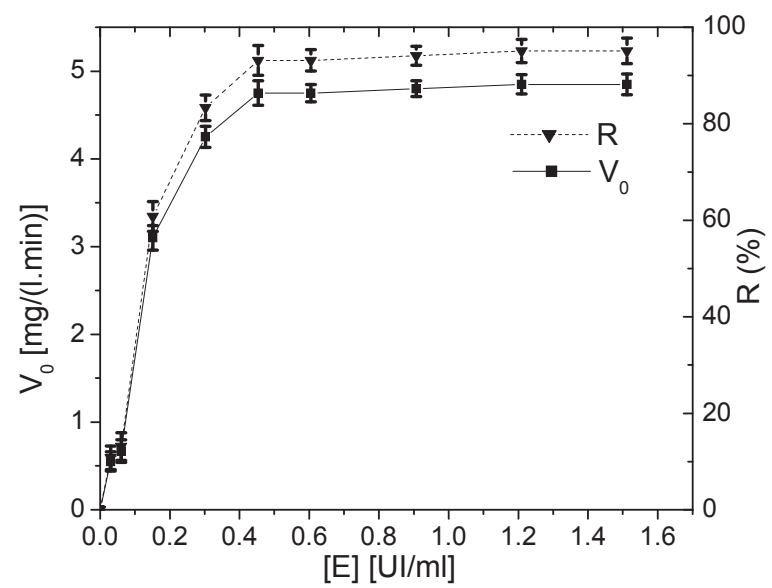

Fig. 7. Effect of enzyme concentration on Congo Red (50 mg/l) discolouration; $50 \mathrm{~mm} \mathrm{H}_{2} \mathrm{O}_{2}, \mathrm{pH}$ 10.0, $10 \mathrm{~min}$.

and Husain, 2007; Matto and Husain, 2009a, b; Ulson de Souza et al., 2007; Maddhinni et al., 2006). This concentration was therefore chosen for standard conditions.

\section{Enzyme concentration}

Initial velocity and percent yield of the reaction increased with enzyme concentration up to about $0.45 \mathrm{UI} / \mathrm{ml}$ of enzyme and did not change further at higher concentrations (Fig. 7).

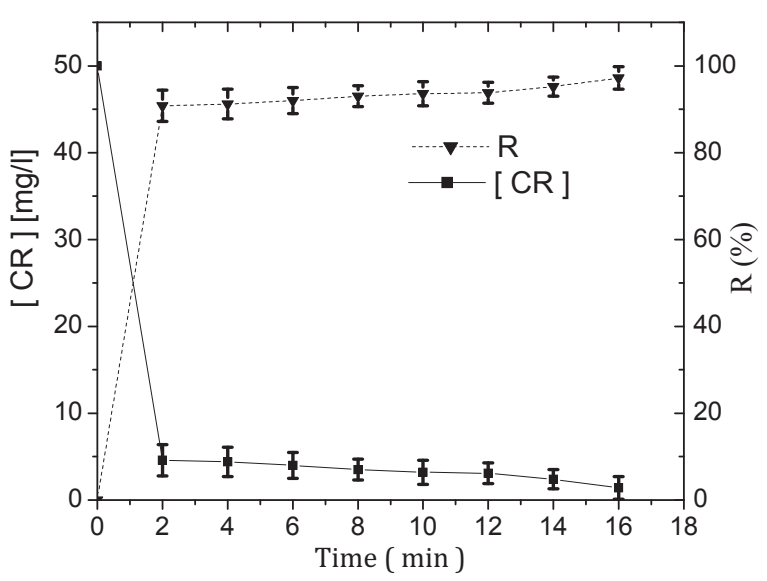

Fig. 8. Degradation of Congo Red under optimized conditions $\left(50 \mathrm{mg} / \mathrm{l}\right.$ Congo Red, $0.45 \mathrm{U} / \mathrm{ml} \mathrm{TP}, 50 \mathrm{mM} \mathrm{H}_{2} \mathrm{O}_{2}$, $\mathrm{pH} 2.0$, and $25^{\circ} \mathrm{C}$ ).

\section{Time course of $C R$ discolouration under optimized conditions}

Under optimized conditions, $90 \%$ of the dye were degraded within the first $2 \mathrm{~min}$, and total discolouration of the reaction mixture was achieved after about 16 min (Fig. 8).

\section{Product analysis}

The absorption spectra of reaction mixtures before and after $96 \%$ discolouration are shown

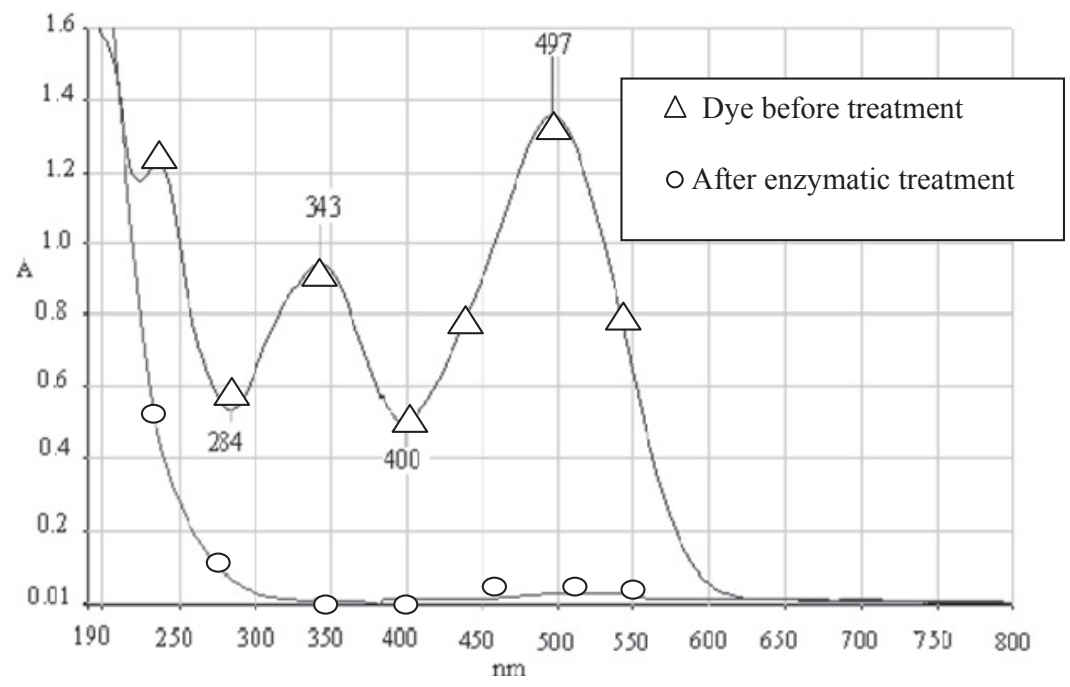

Fig. 9. UV-Vis spectrum of the Congo Red dye before and after enzymatic treatment. 
in Fig. 9. The characteristic peaks of the dye at 343 and $497 \mathrm{~nm}$ disappeared, while a broad peak between 450 and $550 \mathrm{~nm}$ could be observed after completion of the reaction (Torres et al., 2003).

The FTIR absorbance spectrum of CR had an absorbance band at $1446.5 \mathrm{~cm}^{-1}$ which can be attributed to the azo group (Fig. 10b), in agreement with Busignana and Cogrossi (1964). Indeed, these authors examined 43 azo and di-azo derivatives and suggested that the absorption band of $-\mathrm{N}=\mathrm{N}-$ is in the area $1400-1450 \mathrm{~cm}^{-1}$. These peaks were absent from the spectra of the precipitated product after enzymatic treatment (Fig. 10a). In the region from 1600 to $1650 \mathrm{~cm}^{-1}$, there was the appearance of a new band at $1647.1 \mathrm{~cm}^{-1}$ in the spectrum of the precipitated product which could be attributed to an $\mathrm{R}-\mathrm{NH}_{2}$ group. The azo function in $\mathrm{CR}$ had thus been

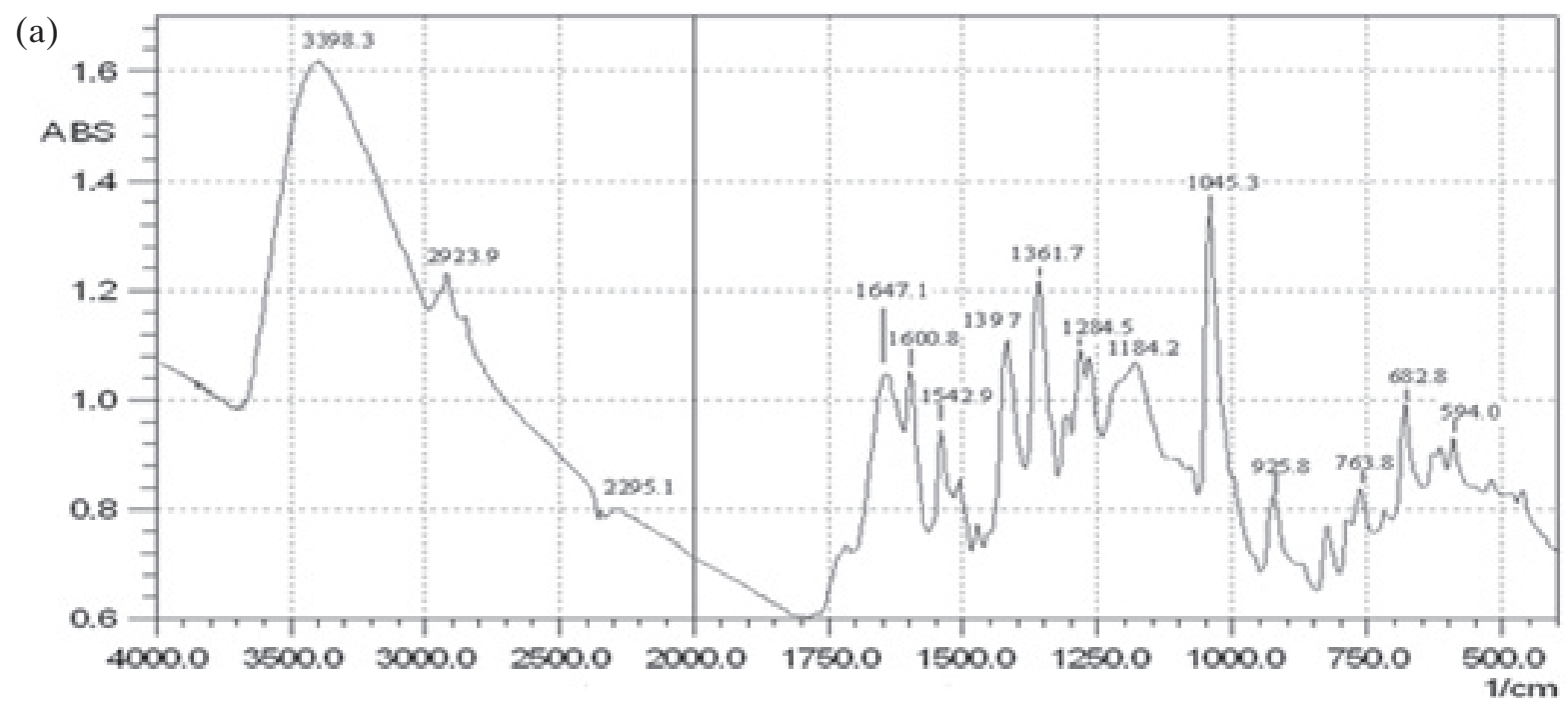

(b)

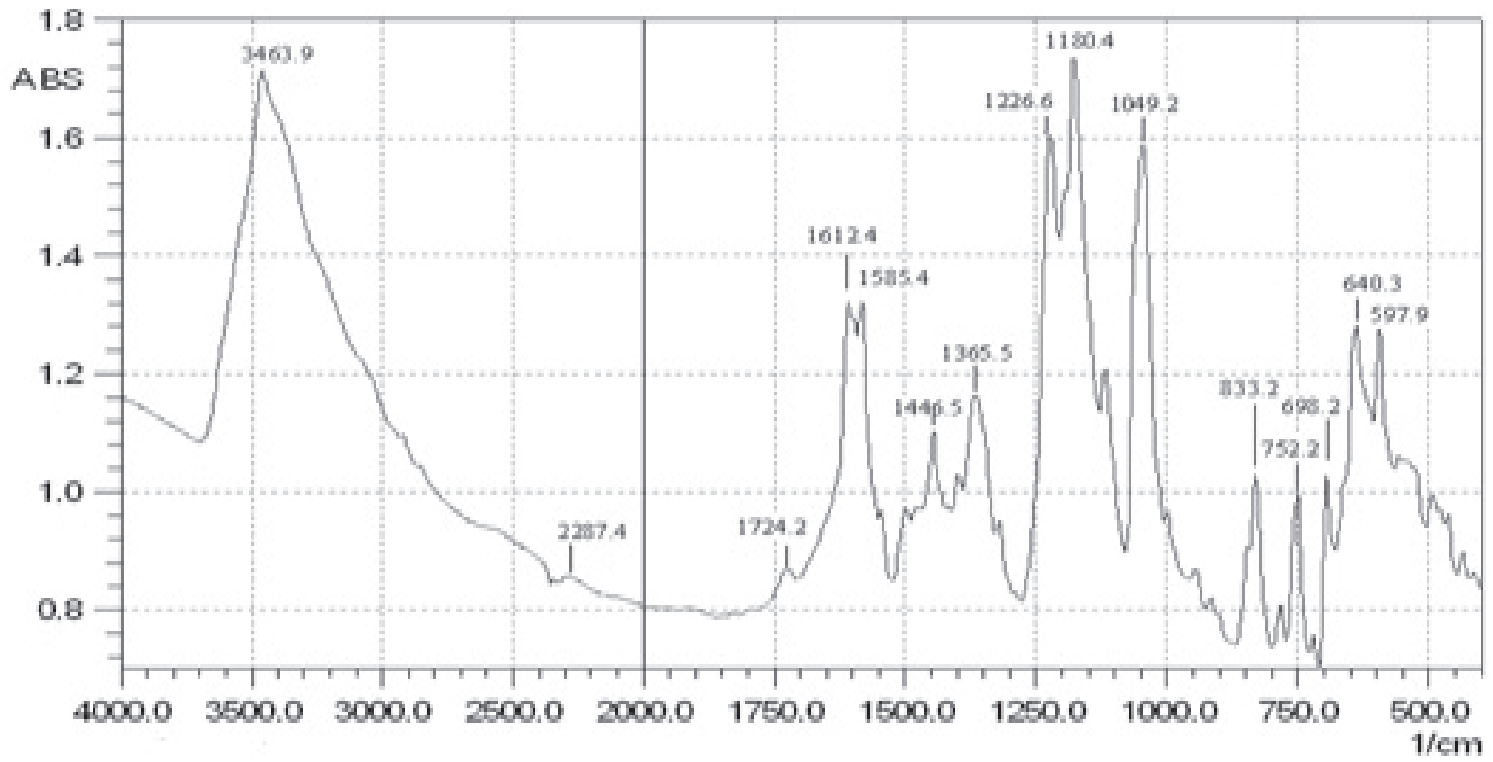

Fig. 10. FTIR spectra of (a) the precipitated product obtained after enzymatic treatment and (b) Congo Red. 
replaced by an amide bond in the course of discolouration. A polymerization reaction was probably the explanation. Full analysis by more sophisticated methods such as mass or NMR spectrometry should help in the identification of the nature of the precipitate.

\section{Conclusions}

Discolouration of $\mathrm{CR}$ using a peroxidase preparation from turnip (Brassica rapa) was investigated. The electron-withdrawing nature of the azo linkages obstructs the susceptibility of azo dye molecules to oxidative reactions. Only specialized azo dye-reducing enzymes have

Bhatnagar A. and Jian A. K. (2005), A comparative adsorption study with different industrial wastes as adsorbents for removals of cationic dyes from water. J. Colloid Interface Sci. 281, 49-55.

Bhunia A., Durani. S., and Wangikar P. (2001), Horseradish peroxidase catalyzed degradation of industrially important dyes. Biotechnol. Bioeng. 72, 562-567.

Busignana P. and Cogrossi C. (1964), Absorption IR du groupe $-\mathrm{N}=\mathrm{N}$ - en colorants azoïques. Tetrahedron $\mathbf{2 0}$, $2361-2371$.

Chatterjee S., Chatterjee S., Bishnu P., and Guha K. (2007), Adsorptive removal of Congo Red, a carcinogenic textile dye by chitosan hydrobeads: Binding mechanism, equilibrium and kinetics. Colloids Surf. A 299, 146-152.

Duran N. and Esposito E. (2000), Potential applications of oxidative enzymes and phenoloxidase-like compounds in wastewater and soil treatment: a review. Appl. Catal. B 28, 83-99.

Guaratini C. I. and Zanoni M. V. B. (2000), Textile dyes. Quím. Nova São Paulo 23, 71-78.

Hai F. I., Yamamoto K., and Fukushi K. (2007), Hybrid treatment systems for dye wastewaters. Crit. Rev. Environ. Sci. Technol. 37, 315-377.

Husain Q. and Jan U. (2000), Detoxification of phenols and aromatic amines from polluted wastewater by using phenol oxidases. J. Sci. Ind. Res. 59, 286-293.

Kulshrestha Y. and Husain Q. (2007), Decolorization and degradation of acid dyes mediated by partially purified turnip (Brassica rapa) peroxidase. Toxicol. Environ. Chem. 89, 255-267.

Maddhinni V. L., Vurimindi H. B., and Yerramilli A. (2006), Degradation of azo dye with horse radish peroxidase (HRP). J. Indian Inst. Sci. 86, 507-514.

Matto M. and Husain Q. (2009a), Decolorization of direct dyes by immobilized turnip peroxidase in batch and continuous processes. Ecotoxicol. Environ. Saf. 72, $965-971$. been found to degrade azo dyes. The results of this study proved that the use of an enzymatic treatment process is a viable approach for the degradation of azo dyes from aqueous solutions. The optimized discolouration reaction is completed within less than half an hour and nontoxic products are formed (data not shown), including an easily removable precipitate and a dye-free supernatant.

Modeling the kinetics of the enzymatic process and studying the effect of immobilization on the overall rate and discolouration yield are under development in order to prove the feasibility of the procedure for subsequent development on an industrial scale.
Matto M. and Husain Q. (2009b), Decolorization of textile effluent by bitter gourd peroxidase immobilized on concanavalin A layered calcium alginate-starch beads. J. Hazard. Mater. 164, 1540-1546.

Meyer U. (1981), Biodegradation of Synthetic Organic Colorants. Academic Publishers, London.

Mohorcic M., Teodorovic S., Golob V., and Fiedrich J. (2006), Fungal and enzymatic decolourisation of artificial textile dye baths. Chemosphere 63, 1709-1717.

O’Neill C., Hawkes F. R., Hawkes D. L., Lourenço N. D., Pinheiro H. M., and Delée W. (1999), Colour in textile effluents-sources, measurements, discharge consents and simulation: a review. J. Chem. Technol. Biotechnol. 74, 1009-1018.

Palmieri G., Cennamo G., and Sannia G. (2005), Remazol Brilliant R decolourisation by the fungus Pleurotus ostreatus and its oxidative enzymatic system. Enzyme Microb. Technol. 36, 17-27.

Purkait M. K., Maiti A., Das S., and Gupta S. (2007), Removal of Congo Red using activated carbon and its regeneration. J. Hazard. Mater. 145, 287-295.

Quintanilla-Guerrero F., Duarte-Vazquez M. A., Garcia-Almendarez B. E., Tinoco R., Vazquez-Duhalt R., and Regalado C. (2008), Polyethylene glycol improves phenol removal by immobilized turnip peroxidase. Bioresour. Technol. 99, 8605-8611.

Regalado C., Garcia-Almendarez B. E., Miguel A., and Duarte-Vazquez M. A. (2004), Biotechnological applications of peroxidases. Phytochem. Rev. 3, $243-256$.

Selvam K., Swaminathan K., and Chae K. S. (2003), Discoloration of azo dyes and a dye industry effluent by a white rot fungus, Thelephora sp. Bioresour. Technol. 88, 115-119.

Shaffiqu T. S., Roy J. J., Nair R. A., and Abraham T. E. (2002), Degradation of textile dyes mediated by plant peroxidases. Appl. Biochem. Biotechnol. 102-103, 315-326. 
Torres E., Bustos-Jaimes I., and Le Borgne S. (2003), Potential use of oxidative enzymes for the detoxification of organic pollutants. Appl. Catal. B 46, 1-15.

Ulson de Souza S. M. A. G., Forgiarini E., and Ulson de Souza A. A. (2007), Toxicity of textile dyes and their degradation by the enzyme horseradish peroxidase (HRP). J. Hazard. Mater. 147, 1073-1078.

Verma P. and Madamwar D. (2002), Decolorization of synthetic textile dyes by lignin peroxidase of Phanerochaete chrysosporium. Folia Microbiol. 47, $283-286$.
Yousefi V. and Kariminia H. R. (2010), Statistical analysis for enzymatic decolorization of acid orange 7 by Coprinus cinereus peroxidase. Int. Biodeter. Biodegr. 64, 245-252.

Zhu H., Jiang R., Xiao L., Chang Y., Guan Y., Li X., and Zeng G. (2009), Photocatalytic decolorization and degradation of Congo Red on innovative crosslinked chitosan/nano-CdS composite catalyst under visible light irradiation. J. Hazard. Mater. 169, 933-940. 